By JACK PLOTKIN

\title{
Treasures Through the Golden Gate
}

$\mathrm{O}$ VER a hundred years ago, prospectors searched for gold where scholars from everywhere now request material from various college and university libraries located near San Francisco. Since a detailed description of each library would consume many articles, this one will highlight only a few.

The University of San Francisco Library, completed in 1949-50, was probably the first in the state to use modular planning, which provided the student with the utmost comfort and convenience for study purposes. Its St. Thomas More collection, purchased in 1951, is one of the best in the country. In addition, it has a Christopher Columbus collection, emphasizing cartographically the many voyages of Columbus.

Toward the ocean is the San Francisco State College Library, completed in 1954. Because of the rapid growth of the student body, the library is already adding another wing. Divided into broad subject divisions, collections center around specialized reference services with open shelf arrangements, thus giving students access to most materials.

On Lone Mountain, one of the most spectacular sights in the city is the San Francisco College for Women. Its Monsignor Joseph Gleason Memorial Library, modeled after one at the University of Seville, has an immense beamed reading room, on the ceiling of which appear the seals of renowned universities. Its collections, essentially

Mr. Plotkin is Chief Circulation Librarian and Lecturer in Bibliography, Stanford University Libraries. those of a consulting reference library, are built around the historical and philological library of Monsignor Gleason. He spent fifty years gathering books and manuscripts, including a manuscript of Pope Leo I sermons (ca. 1150) and thirty-five incunabula.

East of the bay, Berkeley boasts the largest university library west of the Mississippi, that of the University of California, with over 2,100,000 books. In the variety of collections, one finds the Ledru-Rolling Collection of French Revolution pamphlets, the Olschki Collection of early prints of polyphonic and liturgical music and early books about music, the Kerner Collection of Slavic materials to supplement the already extensive holdings on Russian and Slavic Europe, the Beatrix Farrand Collection on Landscape Architecture, and the Setchell Collection on Tobacco.

The 17,000 titles in the Rare Books Department include nearly 400 incunabula and manuscripts ranging from the Hearst Medical Papyrii dating from 2000 B.C. to fifty-six western manuscripts written before 1600 . Besides these, the Bancroft Library, with its wealth of materials on California, the Pacific West, Mexico, and Central America, brings scholars from all corners of the earth to utilize its facilities. In addition, the quarter-million books, manuscripts, and maps make the East Asiatic Library among the three leading American academic research centers in oriental studies.

Farther east in the Moraga Valley lies St. Mary's College. Its library is geared to an undergraduate liberal arts curriculum. The outstanding feature is a 
microfilm collection of California church history belonging to the Fresno, California, diocese. Its curator, Monsignor Jim Cullerton, collected this material for forty years. Furthermore, the library has over 2,000 phonograph records, which can be played on high fidelity equipment.

In East Oakland is Mills College, a liberal arts institution primarily for women. In 1954 the present library doubled in size. Its interior, so subtly decorated that one does not realize where old stops and new begins, uses the various shadings of green found in the campus's eucalyptus trees, creating a rural feeling in the midst of a metropolis. The 10,000 volume rare book and manuscript collection is housed in the Albert M. Bender Room and is widely used in a history of printing course taught by the Reference Librarian as part of the Art Department offerings.

Thirty miles south on the San Francisco peninsula is Stanford University, the second largest university library in California. In the main building are located the general collections and the rare book room which houses, among many collections, the Dirge edition of the Tripitika (the complete Buddhist canon printed in Tibet about 1730), the Sir Isaac Newton Collection, the Felton Library of English and American literature, containing original editions of major and minor authors of the nineteenth and twentieth centuries, and the Memorial Library of Music which includes manuscript scores by Grieg, Mozart, and others.

The Hoover Institute and Library on War, Revolution, and Peace, is housed in its own building on the Stanford Campus. Its collections are unique and world renowned with emphasis on the causes and consequences of twentieth century war, peace, aims and trends, principal revolutionary movements, propaganda, and public opinion.

In addition the Stanford Lane Medical Library (in San Francisco until 1959) is the largest medical collection west of the Mississippi. Requests for inter-library loans arrive from all over the world.

Fifty miles south of San Francisco is the San Jose State College Library, oldest of the state college collections. In 1956 a three story modular structure was completed and connected to the older wing of the library thereby giving a seating capacity for 1,500 students. Plans are already afoot to add another wing. The library is organized into five subject divisions with a separate reading room and an adjoining stack area for each. This arrangement allows free access to the materials, with controls maintained by exit check-out stations.

Nearby is the University of Santa Clara. Its library emphasizes, besides a law collection, an undergraduate liberal arts curriculum. It also has a distinguished California history collection with many mission records. Moreover, as the official library for the Ancient Order of Hibernians of California, it is strong in Irish literature and culture.

Alma College, the only Catholic seminary west of the Rocky Mountains approved by the Holy See, is in the Santa Cruz Mountains. Because it is a professional school with a limited student body, the library collections are related wholly to theology and collateral subjects, with specialization in major Catholic authors who developed theological thought since the Council of Trent.

In conclusion, it is regrettable that this article can describe only some of the "golden" library treasures. Many "nuggets" still exist in the smaller schools of the bay area. The writer knows that all "prospectors" will be welcomed during the July conference. 